\title{
MULTICULTURALISMO NO TEATRO BRASILEIRO
}

\author{
Carmelinda Guimarães \\ Universidade Federal de Goiás
}

O passado colonial do Brasil reservou-lhe um lugar bem claro e definido na divisão internacional do trabalho: país agráriomonocultor, exportador de matéria-prima e importador de produtos manufaturados das economias centrais. Esta condição moldou a estrutura social que aparece composta, basicamente, por duas classes sociais: grandes proprietários de terra e trabalhadores rurais. O regime de trabalho escravo, que permaneceu inabalável no Brasil durante quatro séculos, imprime características que tornam mais complexa esta realidade. A formação da nação - fenômeno histórico de longa duração e, por isto mesmo, responsável por seus traços estruturais - se faz sob a égide da escravidão, forjando um tipo todo especial de relacionamento entre governantes e governados e condicionando a superestrutura ideológica do país.

A situação de dependência desta economia monocultora em face do mercado externo levou o país, no início do século XIX, a uma situação de impasse, pois naquele momento o açúcar - até então principal produto de exportação - passou a encontrar dificuldades de se colocar no mercado internacional, em virtude da concorrência de outros países. A derrocada econômica que se anunciava não ocorre, entretanto, em virtude do surgimento de um novo produto agrícola que viria a ocupar o lugar deixado pelo açúcar: o café.

Não seria exagero afirmar que com o café iniciava-se nova era no Brasil. As mudanças estruturais advindas da economia cafeeira atingem profundamente a estrutura social do país. Do ponto de vista das classes dirigentes nota-se, desde o início, a diferença entre a nova oligarquia cafeeira e sua antecessora, a açucareira. Segundo Celso Furtado, a diferença reside no fato de que, na economia açucareira, a produção, nas mãos do proprietário rural, é desligada da comercialização do produto, que é feita por outro agente social, o que levava o latifundiário a perder a visão do todo do processo econômico, 
do qual é protagonista, enclausurando-o mais ainda no seu restrito universo rural. O "barão do café", por sua vez, assume todas as fases de sua empresa, ligando a produção à comercialização e ganhando o controle, portanto, sobre todo o processo, o que lhe possibilita maior interferência na esfera política.

Do ponto de vista dos trabalhadores, a grande modernização proporcionada pela economia cafeeira foi a introdução do trabalho livre que vai, de resto, iniciar o processo de corrosão de uma das instituições fundamentais da realidade brasileira da época: a já mencionada escravidão, sustentáculo da economia desde a colonização e "viga mestra"do regime monárquico. O "trabalho livre" acionou um outro processo social: o da imigração. A primeira iniciativa da oligarquia rural, de trazer colonos europeus para trabalhar na agricultura, foi de Nicolau Campos Vergueiro, que, em 1840, trouxe colonos para sua fazenda de café em Limeira, São Paulo. Em 1855 entraram 2.125 imigrantes europeus no Brasil. No entanto, as péssimas condições de vida oferecidas aos imigrantes provocaram uma queda temporária na entrada de estrangeiros. Assim, por volta de 1870, o governo assumiu a imigração, que foi favorecida nessa época pelos problemas econômico-sociais da Itália que passou a nos fornecer uma grande massa de trabalhadores. A corrente imigratória aumenta e modifica o perfil da classe trabalhadora no Brasil. O próprio fato de se tratar de assalariados já transforma radicalmente as relações capitaltrabalho, dando à empresa cafeeira daquele momento um caráter muito mais capitalista do que a agricultura fundada no trabalho escravo.

Esses colonos vão, mais tarde, engrossar as fileiras do proletariado urbano exigidas pelo início do período industrial no Brasil. Com efeito, grande parte dos estrangeiros que se destinavam ao trabalho agrícola, por motivos os mais variados, mais tarde vão se fixar na cidade. Além da modificação nas relações de produção com o advento do trabalho livre, a economia cafeeira introduz novidades na infraestrutura do país. Dentre elas, destaca-se a expansão da rede ferroviária, que vai dinamizar as comunicações, baratear o custo das mercadorias exportáveis, possibilitar maiores lucros e oportunidades de trabalho. Houve, também, a melhoria dos portos e as primeiras instalações de fábricas de produtos para o consumo interno, tais como alimentação e tecelagem. 
Estas modificações têm como decorrência um processo crescente de urbanização e uma diversificação da estrutura social: o Brasil deixava de ser um país formado basicamente por senhores e escravos; aumentava o setor intermediário, que iria ter uma importância no cenário político do início do século XX.

Não havia o esboço de um "parque industrial", o que expressa a inexistência de um projeto de industrialização. Com efeito, a indústria era um setor secundário na economia do país agrárioexportador. E mais, era dependente desse setor, na medida em que grande parte do capital que deu início à atividade industrial veio da economia cafeeira e os agentes sociais que a ela se dedicaram ou eram oriundos das oligarquias, ou imigrantes bem sucedidos que procuravam cortejar - quando não unir-se até por casamento - as classes dominantes brasileiras. A história da nossa indústria está profundamente ligada à imigração estrangeira.

Os imigrantes operários deram ao Brasil sua força de trabalho, mas difundiram também sua ideologia: o anarquismo, que marcou profundamente os primórdios do movimento operário brasileiro, extremamente combativo na Primeira República. Os operários lutavam arduamente por melhores condições de vida e de trabalho, utilizando, sobrctudo, a greve como instrumento de pressão contra o patronato. Além disso, desenvolviam intensas atividades de educação e propaganda política através de iniciativas culturais, como o teatro, que se transformou num lugar de coesão grupal, preparação ideológica e organização política dos operários para o enfrentamento com a burguesia. É necessário que se reflita um pouco como se deu esta relação entre o capital e o trabalho, ou seja, qual era a realidade em que iria atuar o movimento anarquista.

Durante a Primeira República, o poder econômico e o Estado formavam dois elementos que compunham o que se poderia chamar de dominação harmônica, pelo menos no que se referia à classe trabalhadora. As classes dominantes brasileiras pareciam não compreender que se iniciava um tempo histórico, a exigir transformações nas relações capital-trabalho. Para elas e para 0 Estado, "A questão social era uma questão política". 


\section{Teatro e anarquismo}

Neste contexto sócio-político é natural que, paralelamente às encenações profissionais, apareça um movimento amadorístico, sobretudo em São Paulo, com forte presença do imigrante. Calcula-se que no início do século em São Paulo, $90 \%$ do proletariado urbano era formado por imigrantes de várias nacionalidades, sendo os italianos numericamente superiores aos demais. Este contingente trouxe consigo a sua cultura e, conseqüentemente, sua própria arte, seu próprio meio de expressão. Criaram o seu espaço cultural dentro da cidade e, durante muitos anos, não se preocuparam em atrair para as suas casas de espetáculo outro tipo de público que não fossem os seus compatriotas e descendentes.

Os espetáculos teatrais tinham por objetivo a ajuda mútua (imigrar sempre causa problemas), a aglutinação de compatriotas e a permanência de uma cultura. No caso dos grupos mais ativos politicamente, as experiências teatrais vinculavam-se às atividades longamente desenvolvidas na Europa durante as lutas sociais do período de unificação italiana.

A esses "movimentos filodramáticos" interessava especialmente uma revivência da cultura italiana, tangendo a cópia dos grandes acontecimentos do teatro da época. Era comum o melodrama nas variáveis capa e espada, ou a trajetória sentimental do herói burguês, muito embora, dentro de gênero, fossem muitas vezes escolhidos aqueles em que fossem perceptíveis a contestação, a injustiça. É o caso do Teatro Populare, localizado na rua do Gasômetro, dirigido por Enrico Cuneo, cujo repertório era Galileo Galilei, A Inquisição na Espanha, Os Miseráveis, ao lado de Romeu e Julieta, de Shakespeare, por exemplo. Havia também pequenas comédias dialetais e gestas nacionalistas, como A Morte de Cesare Locatelli.

Os espetáculos eram apresentados em sociedades beneficentes, agremiações, e até mesmo em teatrinhos próprios - o que indica que a atividade teatral visava uma continuidade, uma programação a longo prazo. O teatro mais comprometido, os grupos anarquistas, por exemplo, desenvolvia-se nas chamadas veladas (aos sábados à noite) entre hinos, conferências, poemas, tômbolas e baile, segundo Mariângela A. de Lima. Essas veladas operárias ocorreram, sem modificações significativas, durante praticamente trinta anos. 
Visavam a propagação de uma unidade ideológica ameaçada pelas alterações concretas nas condições de vida.

A este caráter, originariamente didático e doutrinário, acrescentou-se o político ideológico, ligado ao pensamento libertário que procurava uma consciência de classe, denunciando as arbitrariedades do sistema e reivindicando melhores condições de vida. O teatro passou a ser encarado como instrumento de transformação de pessoal e, conseqüentemente, social. Muitas vezes por necessidade - utilizou-se o drama romântico, o melodrama, seus personagens e situações que, enfatizados, serviam perfeitamente à causa.

Os atores filodramáticos ("engajados" ou não) pertenciam a ofícios diversos. Não havia destaque entre eles. O resultado era avaliado pelo trabalho do conjunto e não pelo desempenho individual.

No caso do teatro feito por anarquistas, a imprensa operária voltava-se quase sempre para o ponto de vista doutrinário e pouco se preocupava com inovações ou qualidades estéticas. A dramaturgia européia, no caso, era suficiente para divulgar a ideologia libertária, pois sendo seu cerne o conflito indivíduo versus organização social, não havia necessidade de adaptação às especificidades locais. O problema era universal. Os autores mais representados no teatro de tendência anarquista foram os italianos Pietro Gori (Primeiro de Maio) e Gigi Damiani (Viva Rambolot, Osteria Della Vittoria, Na República); o francês Jean Grave (Responsabilitá, representado em italiano); o português Neno Vasco (O Pecado de Simonia e Greve de Inquilinos). Com o correr do tempo, começaram a aparecer os textos brasileiros: O Semeador, do mineiro Avelino Foscolo, Avatar, do riograndense Marcello Gama e, mais recentemente, A Bandeira Proletária, do alfaiate, vidreiro e líder Marino Spagnolo.

Pelo nome do grupo reconhecia-se sua ideologia: "Pensamento e Ação", "Germinal", "Belo Sexo", "Gabrielle D'Annunzio", "L'Amore all'Arte", "Principessa Dei Dollari". O espírito dos "filodrammatici" não libertários estão muito bem sintetizados nas palavras de Francisco Pettinatti, por ocasião das comemorações do $23^{\circ}$ aniversário do "Circolo Filodrammatico Amore all'Arte", reproduzida por Miroel Silveira em sua tese de doutoramento A Comédia de Costumes - Período Ítalo-Brasileiro: "Hoje me sinto o mesmo garoto irriquieto que acorria às vossas 
representações, das quais vós, Ugo Rizzo - velho e incorrigível idealista - éreis o sustentáculo, e vós, Rizzetti e Finetti, éreis a alma (...) Recordo que muito antes das apresentações dos elencos profissionais provenientes da Península, já o público paulista conhecia as mais recentes produções de Rovetta, Zambaldi e Bracco, através das interpretações, nem sempre perfeitas, é verdade, dos filodramáticos locais (...)Saindo do tumulto das fábricas, das oficinas, dos escritórios depois de uma longa e interminável jornada, vós sentíeis a necessidade de vos reunirdes"...

Desse movimento, saíram Itália Fausta (Faustina Polloni), que fez suas primeiras aparições na "Societá Fuilodrammatica Paolo Giaconetti", em 1898; e Nino Nello (Giovanni Vianello), surgido em 1911, nas apresentações do "Circolo Recreativo Pietro Mascagni".

"À medida que se fazia a integração, foram desaparecendo os filodramatici e seus grupos. "Muse Italiche" resistiu regularmente até a década de cinqüenta. Em período bem mais próximo, descendentes daqueles primeiros italianos fundaram 'I Guitti', cujas apresentações, comandadas por Athos Abramo e com cenários de Lívio, além do excelente nível, possibilitaram - segundo a tradição - o surgimento de uma nova atriz para os nossos palcos: Lélia Abramo".(Cit. Suplemento do Centenário do "O Estado de S. Paulo", 27/12/93).

\section{Tradição sem ruptura}

O movimento amadorístico dos imigrantes, exceto por eventuais contribuições de intérpretes, em nada se relacionou com o teatro profissional de então. Este, longe das preocupações classistas daquele, prosseguiu com sua crítica política limitada às circunstâncias da comédia de costumes ou, de forma mais irreverente, em cima dos fatos cotidianos, nas revistas.

Nosso teatro, nos primeiros anos do século XX, caracterizouse pela permanência: foram conservados os traços desenvolvidos depois do Romantismo, sem dar origem a novos desenvolvimentos. Continuaram sendo exploradas as revistas, operetas, burletas e os dramas de capa e espada. Embora as primeiras correspondessem ao gosto do público e ao investimento comercial, foram muitas vezes apontadas como causa preponderante da nossa decadência teatral.

A decadência existia, de fato, mas que fosse por causa das revistas, é discutível. Em um dos muitos ataques a esse gênero, o ator 
Cardoso da Motta procura atingir Artur Azevedo, que, além de comédias românticas e burletas, escrevia as mais famosas revistas da época. Afirmando ser esse gênero "o mais canalha e impróprio de ser levado à cena", da Motta afirma que A Filha de Maria Angu, paródia a La Fille de Madame Angot, feita por Artur Azevedo, foi o agente desencadeador dessa "longa série de disparates". A esses ataques, o ilustre comediógrafo responde com seu notável bom humor, afirmando que, ao chegar ao Rio de Janeiro em 1873, vindo do Maranhão ( sua terra natal), já muitas revistas e paródias faziam sucesso na capital. Cita, por exemplo, A Baronesa de Caipó, paródia a A Grã Duquesa de Gerolstein, que arrastava muitidões ao teatro São Luís, acrescentando que, à época, comentava-se muito a paixão do Imperador pelo espetáculo, do qual assistiu "umas vinte reapresentações consecutivas". Dá-nos, ainda, notícias de outras contrafações dramatúrgicas, como duas ao Barbe-Bleu: uma, Barba de Milho, assinada por Augusto de Castro, e outra, Traga-Moça, autoria de Joaquim Serra, conceituado jornalista. Refere-se, ainda, a uma paródia a Orpheé aux Enfers, cujo título era Orfeu na Roça. Termina por dizer a Cardoso da Motta que não pode ser responsabilizado pela "dêbacle" teatral; apenas plantou e colheu "os únicos frutos de que era suscetível o terreno que encontrei preparado".

O que não consta da reposta de Artur Azevedo é que sua "plantação" resultava nos melhores frutos do teatro daquele tempo. Suas peças são montadas até hoje, mantêm-se atuais, e não pouca influência exerceram sobre os comediógrafos ao longo do século passado.

Com a colaboração de outros autores, especialmente Moreira Sampaio, Azevedo escrevia e encenava suas famosas "revistas do ano", onde abordava, criticamente, os fatos sociais e políticos que mais se destacaram no ano interior. A primeira, feita em colaboração com Lino Assunção, foi $O$ Rio de Janeiro em 1877. Embora não estivesse inaugurando o gênero, seu sucesso foi estrondoso, o que levou muitos outros a realizarem espetáculos, quase sempre medíocres, na tentativa de extrair o êxito do mesmo filão.

Homem de teatro, ao qual se dedicou até seus últimos dias, a Artur Azevedo não faltavam preocupações com os destinos dessa arte entre nós. Ainda que atendendo com fidelidade e constância aos apelos de público que the exigia anualmente as revistas de sátira ìs 
vicissitudes políticas ou à louvação aos sucessos, não transigia com sua consciência artística. Dedicava-se também às comédias de costume, para que não se perdesse o hábito de assistir àquilo que achava ser o verdadeiro teatro: "O teatro que mais convém aos países novos", escreveu certa vez, "é o teatro dos costumes, e esse, deixem lá, é o verdadeiro teatro".

Veremos, no entanto, que mesmo entre as companhias estrangeiras em suas frequientes visitas aos nossos palcos, o chamado "teatro ligeiro", com suas operetas e zarzuelas, era o mais constante. Algumas casas de espetáculo optam claramente pelas "variedades", como o Teatro Politeama, de São Paulo, que em 1901 foi transformado em café-concerto, onde, por muitos anos, cantores e ginastas atraíam o público. O cinema, nesse período, começa a utilizar não só a mesma que o teatro para propagando no jornal, como também suas casas de espetáculo.

\section{Origens da Revista}

$\mathrm{Na}$ última década do século passado, a revista estava no apogeu, revelando-se gênero excepcionalmente bem aclimatado às necessidades do público. Como forma teatral, a revista (que provém da tradição portuguesa) é, na verdade, um exemplo da dissolução do modelo dramatúrgico diante da realidade da representação cênica. É uma forma derivada da opereta, por sua vez derivada da ópera. A opereta que dá origem à revista é, mais especificamente, a zarzuela gênero de obra musical que tem por vezes uma unidade temática frágil, mas tem o direito de abrigar todos os estilos musicais e coreográficos num único espetáculo. Ininterruptamente as companhias espanholas de zarzuelas afluem aos palcos paulistas e cariocas, chegando a caracterizar algumas casas de espetáculo como especialistas no gênero - comenta a historiadora Mariângela A. de Lima.

Foi a partir da estrutura narrativa já esgarçada e aproveitando a condescendência para com a miscelânea de estilos, que se deu início em Portugal e no Rio de Janeiro a esse gênero de espetáculo, entremeando aos números musicais pequenas intervenções "declamadas", geralmente em versos de feitura apressada. Cenas cômicas extraídas da crônica de costumes da cidade, do ouvir-dizer, da fofocada política, da crônica policial e do próprio ambiente da 
cidade. A relação com o fato mencionado é invariavelmente cômica, recorrendo às figuras da ironia da paródia. Dessa salada estilística, feita de canções ligeiras, piadas e rimas fáceis, emerge um panorama satírico do cotidiano que nenhum outro gênero até então ousara encarar. Todos os nomes depreciativos que a crítica jornalística utilizava para ver gastar esse gênero não lhe tiram a glória de ser considerado "gênero livre", em contraponto a uma arte dramática ciosa do modelo e da conformidade a uma tradição.

Para compor uma revista é preciso que o autor seja um bom observador, mas é preciso sobretudo que se posicione, faça viver o acontecimento "real" através do comentário crítico sintetizado em poucas e eficientes palavras. À liberdade de compor corresponde uma exigência maior ao dramaturgo, que não parte da base sólida de um gênero, mas sim de uma relação pessoal e crítica com a vida do seu tempo. É essa combinação fortuita que permite o aparecimento de Artur Azevedo, comediógrafo de recursos até hoje não igualados pela dramaturgia brasileira.

No seu período áureo, estranhamente, a revista não estendeu sua influência para outras formas de composição de texto. Depois de Artur Azevedo, os outros autores dramáticos se conformarão aos gêneros mais tradicionais, evitando pudicamente esse território um tanto escuso do gênero livre.

Sem ser exatamente uma ruptura com a tradição dramática brasileira, a revista foi uma espécie de transição entre a comédia de costumes do século XIX, inaugurada por Martins Pena, e sua forma mais recente, a "comédia brasileira", filiada à comédia romântica, ajustada ao esquema fixo das companhias profissionais - com a Ingênua, o Galã, o Centro Cômico etc. - e alguns resquícios da farsa introduzidos através de personagens secundários (vizinhos, criados, transeuntes). A revista adaptava o clima da belle-époque francesa às transições sócio-políticas locais, numa visão crítica e irreverente; enquanto que a "comédia brasileira", buscando o riso em lugar da gargalhada, tenta chegar ao reino da graça, com uma dramaturgia de feições mais delicadas. 


\section{As encenações}

Em 1900 foi inaugırado em São Paulo o Teatro Santana, com a peça de Pinheiro Machado, Helena, pelo grupo cênico 6 de Janeiro, experimentando com sucesso a iluminação elétrica. Consta que nesse ano o maior êxito coube à companhia de Silva Pinto, que apresentou a revista de Artur Azevedo $O$ Gavroche; enquanto que a Companhia Dramática de Teatro Moderno (portuguesa), dirigida por Lucinda Simões e Cristiano de Souza, causou desgosto à crítica com a montagem, "aos moldes europeus", de uma peça de Ibsen. Nesse ano, segundo o jornal "O Estado de S. Paulo", registrou-se intenso movimento teatral no interior, sem dúvida devido à riqueza dos centros cafeicultores.

As estrelas que brilhavam em nossos palcos até 1914, quando da eclosão da I Guerra Mundial, vinham d'além mar. Dezenas de companhias européias, especialmente de Portugal, da França, da Espanha e da Itália apresentaram-se em São Paulo e no Rio de Janeiro. Em um levantamento desse período, constatamos assiduidade de várias delas - Companhia Dramática Portuguesa; Conpanhia Gabrielle Réjane; Companhia Antoine ; Companhia Portuguesa de Eduardo Vitorino; Companhia Afonso Taveira - vinham para cá quase todos os anos. Mais esparsamente, a Espanhola de Zarzuelas Sagi-Barba; as italianas de Vergiani, de Bolognesi, de Vitale, de Tina di Lorenzo, de Novelli, Cittá do Milano, de Scognamiglio-Caramba; as portuguesas de José Loureiro, de Aura e Adelina Abranches, de Grijó, de Chaby, do Teatro Avenida de Lisboa, e outras tantas, incluindo a alemã de Operetas Lahoz. Grandes figuras do teatro, ocasionalmente, marcam presença nessa crônica, entre elas Eleonora Duse, Coquelin e Sarah Bernhardt, que, ao se apresentar no Politeama, em 1905, sofreu o acidente que, mais tarde, provocou a amputação de uma de suas pernas. Tão grande era o trânsito das companhias estrangeiras por nossos palcos que só no ano de 1911 nada menos do que 22 delas se apresentaram em São Paulo.

Em que contribuíram - ou poderiam ter contribuído - essas companhias para o progresso do Teatro Brasileiro, é matéria de difícil avaliação. Raras vezes a imprensa nos dá notícias de inovações estéticas, como na crítica de "O Estado de S. Paulo" sobre a apresentação de Suzanne Després no Teatro Santana, com Le Détour de Bernstein: 
"Suzanne Després tem no papel de Jacqueline a ocasião de nos mostrar toda a simplicidade de seus processos, todo o naturalismo de sua arte enormemente humana"...

E a crítica se alonga na descrição da qualidade interpretativa da atriz, realizada por processos "que maravilham e encantam". Referiam-se, na realidade, à escola desenvolvida em França por Antoine, o Naturalismo, que despertava o interesse de algumas figuras do nosso teatro.

As preocupações estéticas em relação a processos criativos, no entanto, eram menores do que outras, de ordem literária. Ao mesmo tempo que algumas críticas lamentavam a pouca cultura da platéia, incapaz de entender na inteireza dramas como Hedda Glaber (representado por Eleonora Duss, em 1907), ou Pai de Strindberg (levado à cena pelo Teatro Dona Maria, de Lisboa, com atores portugueses e brasileiros), outros preferiam atacar diretamente as companhias, os produtores culturais, por não cuidarem de elevar o nível intelectual do repertório. Estes críticos sublinham as montagens feitas às pressas, tornando impossível aos atores sair dos clichês interpretativos e exagerar nos esgares, nos artifícios melodramáticos.

Em outras palavras, o que a crítica reclamava era a baixa qualidade do teatro em todos os níveis, suas mínimas feições nacionais; debatia-se contra os males do teatro ligeiro, contra a moda que se alastrava em alguns teatros de se realizarem várias sessões por dia, contra a ineficiência dos atores e a pornografia.

Em 1914, o ano da eclosão da I Grande Guerra, muitas companhias portuguesas, italianas e espanholas de operetas, vaudevilles e revistas, apresentaram-se no Rio de Janeiro e em São Paulo. Mas, sobretudo no Rio, várias empresas brasileiras procuraram voltar seu esforço a outros gêneros.

A companhia de Francisco Marzulo dedicou-se aos dramas e ao gênero livre, apresentando $O$ Galinheiro e $O$ Língua de Fora de Tristan Bernard, É do Contrário, de L. Forest; O Mistério do Quarto Amarelo, de Gaston Leroux; e outras. Mas terminou encerrando suas atividades nesse ano. Eduardo Vitorino organizou uma companhia de dramas e comédias, para o Teatro Apolo, excursionando em seguida para o sul. No elenco, entre outros conceituados atores da época, estava Leopoldo Fróes, que, ao voltar do Rio Grande do Sul, 
organizou nova companhia - a Nacional de Dramas, Comédias e Vaudevilles - que teve vida curta. Eduardo Pereira e João Barbosa organizaram a Companhia Dramática João Caetano, dedicada sobretudo aos dramas, encenando Os Cáftens, de Lopes Cardoso; A Dama das Camélias, O Conde de Monte Cristo, Malquerido, O Mártir do Calvário, entre outras peças.

As 16 salas de espetáculos existentes em São Paulo foram, nesse ano, ocupadas, a maior parte do tempo, por empresas estrangeiras. Mas o destaque foi para a Companhia de Revistas, Operetas e Vaudevilles, que tinha o ator Brandão, o "popularíssimo", como principal figura, e apresentou a primeira revista paulista de sucesso: São Paulo Futuro, de Danton Vampré e J. Nemo, com músicas do maestro F. Lobo.

No repertório da maioria das empresas, predominavam espetáculos como Não Pode..., de João Só e Raul Martins; O Botão da Calça, Flor de Virtude, O Pauzinho, Fandaguassu, A Mascarada, Sempre no Antigo, e outras peças cujo mau gosto iniciava no título, desencadeando a ira da crítica.

Em outubro, foi apresentada a segunda revista de sucesso paulista: Só Pra Falar, de Cardoso de Menezes. No fím de 1914, estreou a Companhia de Operetas e Revistas de Leopoldo Fróes, com 58 peças no repertório e anunciando-se como "a mais completa vitória do teatro popular".

A temporada de 1915 traria indicações de novos tempos. No Rio de Janeiro, foi marcada pelo surto de comédias ligeiras e pelo sensível decréscimo do interesse do público pela revista e pelo teatro musicado por sessões. Das companhias que se dedicavam ao gênero, somente a Pascoal Segreto e a José Loureiro (em curtas temporadas) se mantiveram estáveis e com amplo repertório (de qualidade). A de Antônio de Souza obteve êxito com a revista A Última do Dudu, especialmente pela presença de Brandão, o "popularíssimo", no elenco. No gênero, ocorreu também um fato inédito: pela primeira vez apresentou-se no Rio de Janeiro uma companhia paulista, a de Operetas e Revistas do Teatro de São José.

Outro fato inédito: as companhias nacionais de declamação encenavam, de preferência, autores estrangeiros; entretanto, a companhia Portuguesa de Adelina - Aura Abranches e Alexandre 
Azevedo, apresentou Anita, episódio dramático dos brasileiros Gomes e Olival Costa.

Os "novos tempos", mais do que na produção efetiva, estavam indicados pela ausência de grande parte dos elencos estrangeiros que sempre por aqui se apresentaram. Isso, fato concreto e imediato, tinha desdobramentos. A curto prazo, isso ampliaria a discussão sobre o teatro nacional e o repúdio ao seu espírito extremamente alienado e, de certa forma, anti-artístico.

Entretanto, no período que vai até o início da guerra, apesar de todas as críticas negativas e do muito pessimismo quanto aos destinos do nosso teatro, deve-se reconhecer que não faltaram tentativas, da parte de algumas empresas, por espetáculos mais empenhados. Em São Paulo, o esforço maior foi o de Enrico Cuneo, à frente do "L'Amore all'Arte", do movimento teatral ítalo-paulista, que chegou a instalar pequeno teatro na Rua do Gasômetro, onde levou repertório em que se mesclavam libelos anarquistas a obras shakespereanas; dali saiu uma das maiores atrizes brasileiras: Itália Fausta.

No Rio de Janeiro, em 1906, é inaugurado o Conservatório Dramático e Musical. Dois anos mais tarde, organiza-se a Companhia Dramática Brasileira, sob direção de Artur Azevedo, que estreou no Teatro da Exposição Nacional, na Praia Vermelha. Pelo repertório pode-se observar o esforço nacionalista da Companhia. Destacaramse, dentre outras, as comédias Não Consultes Médico, de Machado de Assis; O Noviço, de Martins Pena; As Doutoras, de França Júnior; $O$ Defunto, de Felino de Almeida; o drama Deus e a Natureza, de Artur Rocha; as peças Quebranto, de Coelho Neto; Anjo, de José de Alencar; História de Uma Rica, de Pinheiro Guimarães; Vida e Morte, de Artur Azevedo; Vende-se, de Coriolando Durand. Entretanto, Artur Azevedo faleceu a 22 de outubro desse ano. A Companhia Dramática Nacional, agora Artur Azevedo, ainda excursionou pelos demais estados com muito êxito, vindo a se dissolver em seguida.

\section{Desponta o nacionalismo}

Em agosto de 1914 teve início a I Guerra Mundial, que acabaria exercendo enorme influência no desenvolvimento e fortalecimento do teatro nacional. De imediato, devido à compressão econômica, entraram em crise as casas de diversão, foram fechados muitos teatros, e as Companhias estrangeiras que sistematicamente 
vinham para cá deixaram de fazê-lo, assim como muitas que aqui se encontravam foram obrigadas a permanecer. Isso não significa que algumas outras, ao longo do período da guerra, deixassem de atravessar o oceano - apenas diminuiu sensivelmente o fluxo. Entre as novidades estrangeiras, consta a estréia em 1915, no Rio de Janeiro, da primeira Companhia Mexicana a visitar o Brasil - a de Operetas de Esperanza Íris, que, a partir de então, voltou muitas outras vezes. Destacaram-se, também, a presença em nossos palcos de duas grandes figuras da dança: Isadora Duncan, em 1916, e Nijinski, no ano seguinte.

Mas com a ausência de grande parte dos elencos estrangeiros, foi aberto espaço para que os atores brasileiros pudessem impor seu talento. Firmam-se junto ao público nomes como os de Leopoldo Fróes, Itália Fausta, Abigail Maia, e outros aparecem para logo se firmarem, fundando suas próprias companhias, caso de Procópio Ferreira, Jayme Costa, Alda Garrido. Muitas novas companhias são formadas, a maioria tem vida curta, algumas resistem por muitos anos.

Em 1916 foi inaugurado o Teatro da Natureza, no Campo de Sant'Ana, Rio de Janeiro, experiência que vinha sendo amadurecida por João do Rio e Alexandre Azevedo, e era constituída por uma série de espetáculos ao ar livre, à semelhança do Teatro Livre de Orange, em Nimes. O anfiteatro comportava setenta camarotes, mil lugares distintos, mil cadeiras, mil populares, e dez mil pessoas em pé. O cenário - colunas jônicas tendo ao fundo a própria vegetação do parque - era de Jaime Silva. A direção geral era de Alexandre Azevedo, Cristiano de Souza e do Ciclo Teatral. No elenco, alguns dos maiores nomes do teatro da época, entre os quais, Itália Fausta, Maria Falcão, Adelaide Coutinho, Ema de Souza, Apolônia Pinto, Judith Rodrigues, Alexandre Azevedo, João Barbosa, Francisco Marzulo. Foi inaugurado a 23 de janeiro, com Orestes de Ésquilo, traduzida em versos por Coelho de Carvalho. Seguiram-lhe: Bodas de Lia, de Pedro Rodrigues; Antígona e Édipo Rei, de Sófocles; O Mártir do Calvário, de Eduardo Garrido, cujas apresentações foram em parte prejudicadas pela chuva.

Ainda em 1916, foi criada a Academia Dramática Brasileira, por João Barbosa, Francisco Mesquita, Mário Arozo e outros. Surgiu também, embora sem êxito, um movimento em defesa dos direitos autorais. 
Em 1917, criou-se a Companhia Dramática de São Paulo, sob direção de Gomes Cardim. A empresa, que mais tarde passaria a ser Companhia Dramática Nacional, tinha ambições artísticas e procurava um repertório de alto nível. Estreou no Teatro Boa Vista com a peça de Kistemaeckers Labareda, que, já por sua origem, acionou um movimento de protestos nacionalistas, como este de Armando Prado:

“A predileção pelo exótico, o desprezo das tradições nacionais, o cosmopolitismo disvirilizador, esta nossa insuportável moléstia, por preguiça ou ignorância, copiarmos covardemente o que é estrangeiro, em vez de trabalharmos na feitura de uma civilização original, (...) diante da concorrência da literatura dramática e do teatro alienígena, mataram aquele nativismo ingênuo e sadio que levava nosso povo a amar o teatro brasileiro".

Tal discurso é apenas um exemplo dos muitos outros proferidos na época. Sentia-se já, em nível da dramaturgia, um crescimento qualitativo aliado à concorrência nacionalista. Desponta um autor que marcaria profundamente nossa comédia: Oduvaldo Vianna. Suas primeiras peças - Amor de Bandido, Ordenança do Coronel, Amigos do Peito - já eram conhecidas e apreciadas por volta de 1917.

Esse era o "novo tempo".

A atividade de Oduvaldo Vianna espraiava-se por todos os setores do teatro e animava outros a tentarem novas formas de encenação, mais ligadas à nossa realidade e na direção do Naturalismo. Em 1921, associado a Viriato Correa e Nicolino Viggiani, inaugura o Teatro Trianon, em São Paulo, uma companhia destinada a servir a um teatro "brasileiro autêntico", com peças nacionais e um estilo liberto das formas clássicas impostas pelas companhias portuguesas. Entre outras coisas, exigia-se em cena a prosódia brasileira, a linguagem corrente - o que constituía verdadeira novidade.

De fato, o nacionalismo não era um sentimento inédito na história teatral do Brasil. Ele está presente desde João Caetano, em termos de atitudes e intenções. Mas, na segunda década, especialmente ao impacto do conflito mundial, a procura de soluções nacionais para nossos problemas, quer artísticos, quer político-sociais, se intensifica. A luta de classes, embora desigual, já atinge 
praticamente a todos os setores trabalhistas. A incipiente industrialização determina o aparecimento de uma classe média urbana que, aos poucos, vai se tornando politicamente expressiva. A evidência maior do novo posicionamento da classe média vai se verificar na década de 20, com um movimento que, apesar de pertinente aos quadros do Exército, carrega em si e torna claras as reivindicações da classe média: o Tenentismo. Foi um movimento insurrecional, formado por pequeno número de militares do escalão médio do Exército, inconformados com o modelo excludente de dominação das oligarquias, que os marginalizava na participação política do país.

A simultaneidade das ocorrências históricas não pode ser compreendida se nos ativermos aos fatos históricos dentro de uma cronologia rígida, cuja função é apenas a de tornar mais fácil o estudo. Fermentavam já na segunda década as correntes de pensamento político que eclodiriam ao longo dos anos 20. Interessam-nos, neste caso, duas correntes: a dos Tenentes, enquanto expressão das insatisfações de uma classe que, nas décadas seguintes, mais e mais influência teria no complexo sócio-político nacional; e a dos artistas, que, na tentativa de atualização da arte brasileira em relação à européia, assumem posturas revolucionárias que incidiriam na fundamental Semana de Arte Moderna de 1922.

Aparentemente, o teatro está desvinculado desses movimentos e foi pública e notória sua ausência na Semana de 22. Mas, na realidade, ele participa do contexto em que a modernização e o sentimento nacionalista se confundem e se atropelam. É certo que sua participação é mínima, mas inegavelmente essas novidades influem no seu desenvolvimento.

\section{A comédia brasileira}

Ao término da guerra, em 1918, as Companhias teatrais estrangeiras voltam a invadir nossos palcos, mas, agora, encontram efetiva concorrência das brasileiras. Não que nosso teatro tivesse evoluído técnica e esteticamente - pelo contrário, inúmeros são os testemunhos de sua pobreza e quase indigência, expostos claramente, por exemplo, nos artigos de Antônio de Alcântara Machado, escritos entre 1926 e 1935 - mas, de alguma forma, ele alcançava uma consciência nacionalista que agradava o público. Em sua forma mais 
"culta", esse novo teatro se concretiza via "comédia brasileira", sucessora das comédias de costumes do século passado. Um dos exemplos mais expressivos desse gênero - segundo Mariângela A. de Lima - é a peça de Gastão Tojeiro Onde Canta o Sabiá, de 1921.

A organização básica do texto tem a sua pré-história no drama romântico, que torna a sucessão um pretexto para a revelação dos desígnios das personagens. Há, portanto, um pequeno desentendimento amoroso sobre um pano de fundo largamente pintado, onde se desenham com cuidado as personagens e suas circunstâncias de vida. Uma vez desfeito o engano, que permite a expectativa e atenção necessárias para uma noção de progresso (na verdade, mais acumulação do que progresso), a história chega ao seu bom final com a comprovação de uma tese que permeia a descrição de uma vida panorâmica.

No estudo realizado para o projeto de História do Teatro Latinoamericano, de F. de Toro, Mariângela constata que a cena em Onde Canta o Sabiá abre-se sobre uma casa suburbana do Rio de Janeiro, à beira da via férrea. Há uma varanda, reminiscência de construções rurais, um passarinho à janela. O núcleo familiar, de posses modestas, permeia o seu dia-a-dia de ações triviais e inconseqüentes. Há um marido que acaba sempre por perder o trem. Há um criado que deveria executar uma tarefa no jardim mas que nunca está onde deveria estar. Há um funcionário da estação que gasta seu tempo namorando quando deveria estar regendo a chegada e a saída. Com diálogos continuamente entrecortados, e através da justaposição de características das personagens, Gastão Tojeiro chega à composição de um quadro que poderia ser estático, ou seja, poderia resumir todo o objetivo do texto dramático. O movimento que o texto ressalta é o da rotina, o da repetição das coisas que, por formarem um ambiente agradável e afetuoso como é a relação entre as personagens, acabam conduzindo o espectador a uma idéia de raiz.

É extremamente esse o tema da peça, ou a sua moralidade: raiz. Essas personagens extraídas do mundo semi-rural, às margens de um grande centro urbano, não se distinguem por excepcionalidades no ser ou nos atos. São criaturas preocupadas com a manutenção da ordem doméstica, com a preservação de uma atmosfera da calma e do lirismo rasteiro (simbolizado pelo sabiá). Suas falas são permeadas por referências ao trabalho e à necessidade do trabalho. 
Outras metáforas ajudam a referenciar esse universo. A cenografia não será nem o gabinete nem o telão. É um cenário onde se vê parte da casa e parte da paisagem que a circunda, sem o qual não se poderá compreender esse núcleo familiar. Perto da casa, de um lado, há o rio, lembrança natural e via de acesso que sempre foi, no Brasil, ao interior do país. Paralelamente, outra indicação cenográfica coloca uma ponte sobre o rio, "na qual, se for possível, de vez em quando passarão lentos trens em direções opostas". O trem, ao mesmo tempo é via de acesso ao urbano e um corte na paisagem, a lembrança de que esse mundo tende a tornar-se exíguo e anacrônico. E em defesa dele, Tojeiro coloca em cena um jovem "afrancesado", que despreza essa pequenez e tenta desvencilhar-se da lembrança dessa origem.

"Mas como tudo isso é prosaico! Uma esposa, uma cunhada, uma casa no subúrbio...um sabiá que canta...o que eu não posso compreender é como tu, um espírito emancipado, que abominava toda essa coisa, acabaste sucumbindo como qualquer burguês de idéias atrofiadas! Se me contassem, eu não acreditaria!"

'E lá se vai o pobre Elvidio, afrancesado, 'vendido' ao mundo urbano e aos encantos sub-civilização francesa, ser completamente derrotado pelo autor. Apaixonar-se-á pela cunhada do amigo e, antes de cair o pano, estará reunido aos encantos do subúrbio carioca, trocando juras de amor sob o canto complacente do sabiá. Adeus, Paris!"

Em vez do ufanismo do teatro romântico, que canta as qualidades do país mensuradas pela grandiosidade e pelo insólito da geografia, a "brasilidade" dessa comédia do século 20 reconhece já a divisão entre o mundo rural e o urbano, onde o rural desempenha o papel do arcaico (mesmo em um país tão novo). Por trás desse recuo, dessa recusa à modernidade, há o reconhecimento da fisionomia peculiar desse século: a máquina, a impessoalidade das relações humanas e o cinismo próprio, ao que parece, do mundo burguês.

Sem dúvida, ecoam ainda nestas peças as lembranças de uma matriz forte e inesquecível: A Dama das Camélias, de Alexandre Dumas Filho. E ainda o mesmo ideário, inúmeras vezes mastigados nos dramas e nas comédias românticas de procedência européia. Mas o que as diferencia é a elevação do reverso do drama em protagonista. As virtudes burguesas que entram em cena na Europa, ainda em Emília Galotti, são decantadas pelo progressivo realismo que chega ao 
nosso teatro apenas na década de 20. Não se trata mais de burgueses. Os protagonistas são pequenos funcionários públicos, vivendo na fímbria da cidade e de uma atividade econômica marcadamente urbana. Não são mais prenúncios de uma mudança histórica, mas bolsões de resistência de uma ordem que o século ameaça desbaratar.

A partir desses traços básicos, não podem mais discursar sobre a sua visão de mundo. O espectador deve vê-los, com seus traços positivos, através de uma relação dialógica que se refere apenas ao cotidiano. São personagens deliberadamente incapazes de abstração, cujo sentido de beleza se expressa através da fruição da vida. Podem notar e expressar através das falas suas percepções, mas não poderiam extrair delas uma noção de valor universal para a sua classe ou para o seu tempo histórico.

Como um paradoxo próprio de uma arte que opera por assimilação de modelos, muitas vezes em desacordo com o ritmo peculiar do seu desenvolvimento histórico, e implantação aqui de recursos do realismo, serve a uma aspiração lírica, de retomada da ordem e da predominância de uma sociedade rural no exato momento em que o país toma o rumo da concentração urbana e da diversificação econômica. O texto dramático atende assim a um espaço poético de ordem através da ética familiar e patriarcal, de reduto para a transformação tumultuada do bonde elétrico, da eletricidade, da exportação, da ferrovia e dos tumultos de classe que vêm junto com o crescimento do proletariado.

\section{Teatro e modernismo}

Buscando soluções próprias, o teatro fica isolado das demais artes. A pintura, a música, a arquitetura e, sobretudo, a literatura buscavam procedimentos estéticos dos meios evoluídos, aplicando-se à expressão brasileira. O êxito desse caminho pode ser aferido na obra de Oswald de Andrade, de Mário de Andrade, de Villa-Lobos, de Tarsila, de Anita Malfatti, de Brecheret e outros grandes das nossas artes. Porém, as vanguardas dramáticas das primeiras décadas, as conquistas de Stanislavski, Meyerhold, Appia, Gordon Graig e tantos outros técnicos do espetáculo por aqui não repercutiam. Apesar disso, vozes isoladas se manifestaram próximas aos preceitos modernistas. Um exemplo é o movimento chamado "Batalha da Quimera", liderado por Renato Viana, no Rio de Janeiro, ainda em 1922. 
Mais tarde, em 1927, outra importante tentativa de inovação é levada a efeito, no Rio, por Eugênia e Álvaro Moreyra; o "Teatro de Brinquedo". Sobre o projeto disse Álvaro Moreyra:

"Eu sempre cismei um teatro que fizesse sorrir, mas que fizesse pensar. Um teatro com reticências...Um teatro que se chamasse Teatro de Brinquedo e tivesse como única literatura uma epígrafe do velho Goethe: "Humanidade divide-se em duas espécies, a dos bonecos que representam um papel aprendido e dos naturais, espécie menos numerosa de entes que nascem, vivem e movem-se segundo Deus os criou..." Um teatro de ambiente simples, até ingênuo, bem moderno, para poucas pessoas cada noite...Representaríamos os nossos autores novos e os que nascessem por influência nossa. Daríamos a conhecer o repertório de vanguarda do mundo todo. Os espetáculos de uma peça seriam um gênero. Seria outro gênero a apresentação de programas de pantomimas musicadas, de lendas brasileiras, canções estilizadas, comédias rápidas, motivos humorísticos".

O teatro de Brinquedo instalou-se no sub-solo do Cassino Beira-Mar, adaptado por Luiz Peixoto e Lúcio Costa, com apenas 180 lugares. A troupe era formada por senhoras da sociedade, autores, pintores, compositores, atores (Álvaro Moreyra, Eugênia Moreyra, Briolanja, Mary Sotto Mayor, Aida Ferreira, Di Cavalcanti, Fernando Guerra Duval, Joracy Camargo, Machado Florence, Atílio Milano, Frederico Barreto). Estreou a 10 de novembro com Adão e Eva e Outros Membros da Família. Em dezembro apresentou o Espetáculo do Arco da Velha. Em janeiro os espetáculos foram apresentados em São Paulo e só 10 anos mais tarde as idéias do Teatro de Brinquedo viriam solidificar-se.

De resto, as inúmeras companhias criadas ao longo dos anos 20 só fizeram por manter um tipo de encenação própria das companhias lusitanas do tempo colonial, com pequenas alterações. A modernização teatral se efetuaria apenas nos anos 40, quando a sociedade brasileira, como um todo, entrava em uma nova fase histórica, especialmente com a queda do Estado Novo no final da II Grande Guerra.

O período de 1900 a 1930 foi marcado, do ponto de vista cênico, pelo teatro declamado que se baseava em clichês, grandes gestos, tremores vocais, caretas - um todo histriônico para a 
exteriorização dos sentimentos. Opunha-se a ele o "gênero livre", o "teatro ligeiro", que, embora também viciado e pleno de clichês, apresentava maior espontaneidade. Qualquer que fosse o estilo, entretanto, seu destino era a decadência, a auto-consumação, sem deixar traços relevantes, heranças cênicas ao teatro que surgiria mais tarde, o "moderno".

As críticas de Antônio de Alcântara Machado, publicadas a partir de 1926, eram doutrinárias e não se prendiam à apreciação de peças tomando por base a qualidade média e os padrões estéticos vigentes. Através dessas críticas nos é possível melhor compreensão da realidade teatral da época. Machado debateu-se contra os três alicerces do teatro nacional: a ópera (sobretudo contra o "realejo italiano"tocado ano após ano pelo empresário Walter Mocchi no Municipal do Rio), as temporadas francesas e as companhias vindas de Portugal. Com relação ao teatro nacional, ele procurou apontar os motivos pelos quais não devíamos nos ufanar no Brasil: "A nossa comédia contemporânea nem chega a ser a filha melhorada de $\underline{O}$ Demônio Familiar de José de Alencar ou de Juiz de Paz na Roça de Martins Pena: é irmã delas. Tirando o ambiente, a linguagem, é reprodução fiel das mais velhas. O espírito e a fatura são iguaizinhos. (...) Defeitos gravíssimos. Aponto estes: desnacionalização, banalidade, pobreza de tipos e cenários (...) (O teatro) alheio a tudo, não acompanha nem de longe o movimento acelerado da literatura dramática européia. O que seria um bem se dentro das suas possibilidades, com os próprios elementos que o meio fosse fornecendo, evoluía-se independentemente, brasileiramente. Mas não. Ignora-se e ignora os outros. Nem é nacional nem é universal".

Em suma, propõe ele que dos teatros mais adiantados recebêssemos a técnica, enquanto que a matéria dramática o próprio meio forneceria, desde que não nos limitássemos ao pitoresco urbano e suburbano explorado até então pela comédia de costumes.

Prossegue ele: "Brasileirismo só existe na revista e na burleba. Essas refletem qualquer coisa nossa. Nelas é que a gente vai encontrar, deformado e acanalhado embora, um pouco do que somos. O espírito do nosso povo tem nelas o seu espelhimho de turco, ordinário e barato". 
Enalteceu ainda a companhia de Piolim como sendo a única verdadeiramente nacional; atacou Leopoldo Fróes na ocasião de sua morte, num duro necrológio; fulminou a cultura oficial.

Contudo, a herança que nos foi deixada pelo teatro dos anos 20 prende-se à dramaturgia - matéria que tem merecido vários estudos e que, embora demolida ou execrada pelo crítico modernista, tem o mérito de manter, implicitamente, a reflexão crítica sobre a época.

NOTA: Este pesquisa contou com a colaboração da historiadora Márcia D’Alessio e de Mariângela Alves de Lima. Foi escrita para o Ministério de Cultura de Espanha e publicado no Inventário do Teatro Ibero Americano - Escenários de los Mundos. Fez parte também dos anais da Expo Educação da $54^{2}$ SBPC. 